\title{
Chinese Women's Struggle for Human Rights under the Influence of Marxist Ideology in the Early 20th Century
}

\author{
Lulu Zhang ${ }^{1,2}$ and Xiaonan Hong ${ }^{1}$ \\ (1 Faculty of Humanities and Social Sciences, Dalian University of Technology, Dalian 116024; \\ 2 Public Foreign Languages Department, Jilin Normal University, Siping 136000, China)
}

Keywords: Marxist Ideology; Influence; Women's Human Rights; Awake; Struggle

\begin{abstract}
In the early 20th century, due to the influence of Marxist ideology, China was experiencing an unprecedented social change. With the rise of national liberation movement, Chinese women who were oppressed by four powers also launched a vigorous women's liberation movement, conducted a comprehensive and thorough struggle for their basic rights and social status, and got great achievements in self-determination in marriage, equality in education, political participation, equal employment, etc. Their revolutionary enthusiasm and spirit of the struggle had an important effect on the later feminist striving for women's human rights.
\end{abstract}

\section{Introduction}

That women are inferior to men has become the mainstream ideology in Chinese society, because the feudal patriarchal system has lasted for thousands of years. Chinese women still suffered from the "four rights"-political power, clan authority, husband authority and theocratic oppression even in the early 20th century. In the revolutionary age, the new ideas and new concepts burst fiercely, the oppressions were not remarkable but became invisible and hidden in many aspects of women's life. However, the oppression and resistance coexisted dialectically, so women's resistance was spreading violently in China like a raging fire.

First, the freedom and right of marriage. As Engels said, "In the ancient times, the marriage was arranged by the parents, and the parties had to submit calmly. The marriage love in ancient times was not subjective preferences, but the objective obligation.'[1] The arranged marriage in the Chinese old society existed for a long time and was still the main form of marriage in the early 20th century. The vast majority of women had to succumb to the arrangement of "fate" and went into the unknown marriage after following 'the parents' command and the matchmaker's advice”, perhaps the couple loved each other forever, perhaps the woman suffered from the miserable lives until old age, and they had no choice. Especially for labor women living in the more traditional and conservative countries, "social freedom "or "free love" was more like a beautiful myth and it was difficult to achieve. At the time of the Chinese society, regardless of the city or the country, the traditional feudal ethics like a cane twisted tightly around the majority of women. Because of the oppression from patriarchal family, to bend or to resist became the issue the women started to think and took some action personally after the May 4th Movement.

In the 1920s and 1930s, due to the correct guidance of women's Liberation flag and wide spread of Marxist viewpoint of women, "free love" and "free marriage" became the main melody of female resistance against four rights oppression. Although the old idea still dominated social ideology, 
female groups with new thinking seemed to be outgunned, but they were the few pioneers and opened the way for breaking the thick feudal haze. After the May 4th Movement, more and more women absorbed innovation ideas about love, marriage and family because the women schools were set up and the enrollment system for women was widen by well-known institutions. In this group, the traditional concept about marriage and family began to shake, and they yearned for free love and opposed the arranged marriage, even plucked up the shocking courage to escape marriage in order to revolt the enormous feudal ethics. During the May 4th period, female students were the first group to perceive this revolt burning. "Under the trees and in the dormitory, clusters of people often debated fiercely and blush with shame in full swing. Later, they became to revolve marriage and escape marriage against the old ethics for winning the women's freedom of marriage."[2]

Second, the equal right to education. "The woman are shortsighted so they can't learn knowledge", this saying has become the insurmountable gap for women to go to school and imperial exams in ancient China for thousands of years, till the end of Qing Dynasty, it still showed remaining influences. As everyone knows ancient women's social status, a woman from childhood to youth must be in boudoir so that it was impossible to go to school as men like Arabian Nights. There was a private institution for men in any dynasty, but no special school for women. Rich people would invite a tutor for the daughter to learn playing, chasing, reading and painting, learn how to become a virtuous wife and loving mother in the traditional idea, this boudoir style education "studying alone without friends, limited knowledge and scanty information" should be called the traditional women education. The teaching content of the traditional women education was to learn some of Confucian classics firstly, then study books designed and written for women specially. "So that people can see that there are men and women, men and women should see that between long and short; can see that man, as long as the woman, see short, how?'[3]

Li Zhi, the famous thinker in Ming Dynasty, refuted "The woman are shortsighted so they can't learn knowledge" and criticized the feudal ideology .In the 19th century, more and more overseas scholars were influenced by Marxism and had patriotism to save the country. They brought back the advanced ideas of reform and the concept of education, including the new ideas to break down school banning for women, to advocate coeducation and to emphasize women's education. Liang Qichao valued highly the significance of women's education as the prosperity of the nation, which was very enlightening to promote social acceptance of women's education at the time. At the same time, the Western church began setting up women's school in China. It can be said that the Western church opened the gate for woman to accept the new school education in late Qing Dynasty, which was a challenge to feudal system that women were inferior to men. In 1920s and 1930s after the May 4th Movement, the voice women and men should have equal right to education became higher and higher, the number of women's school and the number of female students grew increasingly. The popularity of women's elementary education had a particular significance for the vast majority of illiterate Chinese women.

Third, the right to participate in politics. "Wisdom men can promote the prosperity of the contry, wisdom women can destroy the country" [4] Women should be far away from the politics since the ancient times. Although several queens with wield state power appeared in later dynasties, such as Lu Hou in the Western Han Dynasty, Wu Zetian in the Tang Dynasty, Ci Xi in the Qing Dynasty and so on. But these were rare exceptions in feudal dynasties for thousands of years, and they held great power behind the screen by the marriage or mother-child relationships with male monarchs, which can not represent the Chinese ancient women political history. In the early 
Republic of China, the women's political participation will was rising while the opposing sound from the patriarchal society can be heard constantly. People with the breadth of vision tried to save the national crisis and propagated the western freedom, equality, democracy and human rights ideas, also advocating equality between men and women and encouraging women's political participation as well as men when the country was in collapsing danger. Before Xin Hai revolution, a group of women having foresight knowledge made great efforts and paved the way for the vigorous development of the women's suffrage movement Chinese later. After they personally participated in the revolution, women's national identity consciousness and responsibility consciousness awakened, and then all kinds of women organization rose as bamboo after a spring rain. This was the prelude of the suffragette movement, a huge giant screen immediately started after the May 4th Movement, the policy and strategies of the women's suffrage movement changed remarkably. In 1924, this national conference movement under the guiding ideology and program of action led the women's suffrage movement to the new stage. In 1930s, the CPC attached great importance to the realization of women's suffrage in the Soviet areas, focused on the training of women cadres and the establishment of women's University and the training class, the political status of women improved greatly. "Historical proof: the majority of working women really got suffrage in the places where was established the revolutionary regime, or whether Soviet Area, anti Japanese bases and Jiefang District have proved this point."'[5] Before the founding of the PRC, the country has been in a period of turmoil warlords, anti-Japanese war, civil war, the women's suffrage movement experienced numerous frustrations, but it enlightened women's consciousness of equality and criticized "If hen crows in the morning, the family will be ruined."[6] As Chinese women really stepped on the political stage.

Fourth, the equal right to employment. 'Independence. Economic independence. Women's economic independence, which is the most important issue in today's society. The women have no job skills so they will have no production capacity. They can't produce, and their economy will never be independent. Their positions will depend on others forever. Their qualifications will be pests of society"[7] With a group of female intellectuals absorbing Marxist view of women and promotion of self-awareness, they began to realize that economic independence was the basic cause to improve the social status of women, and to participate in social labor out of the house and possess their own occupation was the prerequisite for economic independence. Female employment was facing many practical problems.

First of all, the social public opinion demeaned women employment. In the social public opinion, people with a lot of old ideas think that women went out to work was a shameful thing, which violated the good image of the ancient woman that women should stay home, do housework, support her husband and conduct children. Because the community generally believed that the women should take care of children and do housework at home, women's vision was narrow, lacked of knowledge. They were unaware that their right to education, the right to inherit property, the right to employment had been deprived ruthlessly; their economy had to rely on a father or husband just like vines depending on the trees without self. Although some career women got the understanding of the family, they may not get social understanding. Women's enthusiasm to plunge into work sometimes was strangled by invisible pressure of public opinion. The feudal conservative ideas turned into forms of oppression, which would count against women's seeking for economic independence and emancipation of the mind. 'Working women have made up the majority of labor. If women's 
working problems can't be solved properly, other social system will be affected; society won't be stable.’[8]

Fifth, the inequality of occupation system. During this period, the career women can be divided into two groups: industrial female workers who did pure manual labor and female staff who were engaged in education, culture and other social undertakings. As for industrial female workers who were the largest proportion in career women, even though their number was always higher than the number of male workers in the factory, their wages were less than male workers, so the factory owners were more willing to hire women to low cost for high profit. Some educated women were engaged in teachers, librarians, editors, but in seemingly good career fields where these intellectuals gathered, there was still gender inequality phenomenon, for example male teachers' salary was higher than female teachers'. Moreover, there was the usual notion that female teacher was more suitable for basic education, such as the tutor, the kindergarten teacher, the primary school teacher, only a few women who could enter the University as a teacher at that time. In the promotion, male employees had more opportunities of promotion and development space than female staff, and sometimes women's employment opportunities would be seized by male due to gender discrimination. 'Usually, women's education is inferior to men's education so that women's technology and job training are worse than men's. Women's professional status is often in danger of being robbed by men.'[9]

Finally, career women had to face the balance of occupation and family. Many career women who got married would become tired terribly because of the dual pressures of work and chores. Because men did not take the house work at that time, women had to take the responsibility to raise the child and take care of the elderly people after work time, so the community generally believed that women should not go out to work if they got married. In some factories with harsh systems, the women may lose their jobs due to pregnancy. Even in the field of education, women had to face the choice - the family or the career. In the early 20th century, women faced many obstacles in the employment equality, but their resistance determination and unremitting efforts made tremendous progress in self-sustaining and economic independence.

From the above aspects, researchers can see Chinese women experienced a very difficult process to resistant subject from oppressed object - great transition of role in the tumultuous years. Women got across the bar to participate in social activities from family to society, which was not only the success of individual liberation but also the success of female group which got breakthrough in the process of human civilization dominated by male for thousands of years. The achievement that women gained in the free marriage, equality in education, political participation, equal employment and other aspects was closely related to the women's liberation movement with vigor and fiery. Women's revolutionary enthusiasm and the struggling spirit became the eternal fulcrum of liberation movement with the course of the ups and downs. Because of influence of Marxist viewpoint of women and the western democratic ideology, the weak woman in the traditional concept burst out the tremendous energy in the feminist movement and national liberation movement, which enabled people to see the revolutionary momentum women were not outdone by man. Marx identified a huge role played by women in the development of human society in the period of social transformation, in particular, their power beyond people's imagination. "Everyone who understands a little history also knows that there may not be great social change without the enzyme of women."[10] In the first half of 20th century, the women's liberation movement had made the tremendous contribution for the subversion of the feudal monarchy, the expulsion of foreign powers, the promotion of the democratic 
revolution, but also laid the foundation for the establishment of the social mechanism of equality between men and women.

Fund Project. Jilin Province Education Science "12 ${ }^{\text {th }}$ Fiver-year Plan" in 2013: "Research on How Human Thought Influences the Female College Students' Three Values" (ZC13068)

\section{References}

[1]Marx Engles (Volume twenty-first)[M].Bejing: People’s Publishing House,1965:90.

[2] Wang Yizhi. A Female High School in the May 4th Age, the May 4th Movement Memoir[M]. Beijing: China Social Science Press, 1979:518.

[3] Li Zhi (Ming). Ask The Woman Are Shortsighted Book [M].Beijing: Zhonghua Press, 1974:165.

[4]Nie Shiqiao. The Book of Songs Note[M].Jinan:Qilu Press,2000:577

[5]Zhou Yaping. The History of Chinese Women's Participation in Politics[J]. Journal of Jishou University (SOCIAL SCIENCE EDITION), 1992 ,second:78.

[6]Li Min. Note about "Shangshu”[M].Shanghai: Shanghai Ancient Books Press,2000:204.

[7]C.T. YIN. "For Single View" and "Women and Family"[N]: Dagong Newspaper, March 28, 1928. from Zhang Li. On Chinese Women's living condition in the 20 twenty or thirty century [D].Xiamen: Xiamen University, 2007:164.

[8]Zhong Guiyang.Chinese Women's Working Problems[M].Beijing: Women's Bookstore,1935:2.

[9]Guo Zhenyi.Wanyou Libraries(Volume second)Chinese Women's Problem[M].Shanghai: Commercial Press,1937:102.

[10] Marx Engles (Volume twenty-third)[M].Bejing: People's Publishing House, 1975:571. 